\title{
In Search of Lost Fortuna. Reconstructing the Publishing History of the Polish Book of Fortune-Telling
}

\author{
Justyna Kiliańczyk-Zięba
}

The relatively low survival rate for books and printed materials produced in the first two centuries of print is particularly visible in the categories of publications composed in the vernacular intended to appeal to a wide clientele. These books, usually either utilitarian or recreational, were presumably produced in large quantities, in many editions, that required high print runs. But the popular demand that made the printers produce thousands of copies was also the reason why these books perished and left little or no trace in contemporary collections. Karol Estreicher was right in stating that "Latin volumes survived, because the masses did not read them. They were used by scholars, monks, and lawyers - intellectuals who appreciated the results of scholarly effort and thus cherished their books".

There are occasions on which a work is lost to us altogether. It cannot be traced to a surviving copy, and it is only from the archival records that we can make assumptions about the existence of certain texts and therefore editions. Sometimes we are more fortunate: we have access to unique, often fragmentary copies of popular texts. These survivors often suggest that there must have been more editions, produced either earlier or later than the preserved material. These assumptions can sometimes be confirmed through mention of otherwise unknown editions in contemporary documents, as, for instance, booksellers' catalogues or post-mortem inventories. In this way we are sometimes able to demonstrate the existence of lost editions and early texts by examining books produced decades after the original work first

1 Karol Estreicher, Günther Zainer i Świętopetk Fiol (Warszawa: Drukarnia Gazety Polskiej, 1867), p. 63. On criteria that influenced early book survival see e.g. Neil Harris, 'Marin Sanudo, forerunner of Melzi', part 1, La Bibliofilia, 95 (1993), pp. 12-29. On estimates of lost editions see Jonathan Green, Frank McIntyre and Paul Needham, 'The Shape of Incunable Survival and Statistical Estimation of Lost Editions', Papers of the Bibliographical Society of America, 105 (2011), pp. 141-175 and the works quoted by the authors. Research for this article was supported by a fellowship from the Herzog August Bibliothek, Wolfenbüttel. I would also like to thank Mara R. Wade for all the help I received from her during my work on Fortuna. 
found its way to the readers. This is the case of Fortuna abo Szczęście (Fortune or Good Luck) by Stanisław Kleryka, an early sixteenth-century Polish book of fortune-telling.

The complete text of Fortuna has come down to us only in a recently discovered copy that was printed in 1665 , while an incomplete volume represents an edition produced in late 1640 s. $^{2}$ Both copies are unique. This was a lavish, heavily illustrated folio book: the complete edition of 1665 comprises fifty-five leaves and contains over one hundred woodcuts. These, then, were by no means ephemeral books. This was a text valued both by readers, and by the publishers who profited from their sale. Neverthless this substantial and copiously illustrated work survived in only one complete seventeenth-century copy, the sole intact witness to the popularity of this work. This article will demonstrate how later imprints (produced more than a century after the collection of rhymed oracles was composed and first published) can be analysed as books that reflect or even imitate lost editions of the work, at the same time providing evidence as to where and by whom the editio princeps and reprints that followed were issued. Archival records will supply additional information about Fortuna editions that have not survived to the present day.

\section{Books of Fortune-Telling}

Fortuna abo Szczęście is a book of fortune-telling. It is a Polish example of a genre that flourished in the Mediaeval and Early Modern period. Books of fortune-telling (also known as books of divination or books of fate) were collections of oracles rooted in antiquity, along with subsequently composed compilations exploiting the tradition that had developed over the intervening centuries. The oracles were formulated in Greek, Latin, Hebrew, and vernacular languages and the enquirer could get to the relevant oracle by means of dice, cards, calculations based on the position of planets, or the numerical value of the letters from the name of the enquirer. This led to creation of a fascinating body of texts which, unlike more complex and serious astrological forms of divination, provided enquiring minds with amusing methods of discovering the future. ${ }^{3}$

2 Fortuna abo Szczęście (Kraków: Walerian Piątkowski, c.1646-1652 [1649]), copy at Biblioteka Narodowa, Warszawa, Xvir.4.3504. Fortuna abo Szczęście (Kraków: Dziedzice Stanisława Bertutowica, 1665), copy at Strahovska Knihovna v Klastere Premonstratu, Praha, AG XII 25.

3 For a history of the genre see: Johannes Bolte, 'Anhang', in Johannes Bolte (ed.), Georg Wikrams Werke, vol. 4 (Tübingen: Laupp, 1903), pp. 276-278, 319; Johannes Bolte, 'Zur 
Books of fortune-telling were first read in manuscript form, and then quickly passed into print. The first printed collection of oracles was an Italian work by Lorenzo Spirito, entitled Il libro delle sorti. This was published in 1482, in Perugia. Light-hearted and entertaining, Il libro delle sorti enjoyed considerable success, as attested by the number of registered editions: 23 published in Italian by the 1550s and more than two dozen in French, Spanish, English, and Dutch produced by the end of the seventeenth century. ${ }^{4}$ Owing to its popularity, Il libro delle sorti by Lorenzo Spirito also served as a source of inspiration for later compilations. Spirito's followers include, among others, Sigismondo Fanti, the author of Triompho di Fortuna (1527) and Francesco Marcolini, the author of Le ingeniose sorti intitulate giardino di pensieri (1550). To these we may add the German writers who compiled Losbücher, as well as Jörg Wickram, the author of the collection Kurzweil (1539). To these, as we will see, may also be joined the author of the Polish Fortuna.

Books of fortune-telling shared a number of characteristics. One common feature was an apparently complicated structure designed to mystify the readers. Consulting such a book meant finding one's way through a maze of tables and diagrams, wandering among astral representations, talking animals, prophets, and philosophers. Searching for references was intended to build excitement and suspense, and to keep the enquirer in a state of uncertainty about the result of divination. Fortuna abo Szczęście accords well with this tradition. The volume contains 444 rhymed oracles that provide answers to 21 questions listed at the beginning of the volume. These are all restricted to everyday life and personal matters such as health, wealth, career choice, happiness in love and business. After having chosen one of these questions the enquirer first had to find the page where it reappeared, printed above a 'wheel of fortune', i.e. a spherical table of dice casts named after the bird whose image was placed at its centre. The next step was to throw two dice and find the result of the cast at the woodcut diagram, where it would be combined with a name

Geschichte der Punktier- und Losbücher', Jahrbuch für historische Volkskunde, 1 (1925), pp. 185-214; T.C. Skeat, 'An early mediaeval "Book of Fate”: the Sortes XII Patriarcharum', Mediaeval and Renaissance Studies, 3 (1954), pp. 41-54; Willy Louis Braekman (ed.), Fortune-Telling by the Casting of Dice. A Middle English Poem and Its Background (Brussels: Omirel, 1981).

4 Alexander Rosenstock, Das Losbuch des Lorenzo Spirito von 1482. Eine Spurensuche (Weissenkorn: Konrad, 2010), pp. 15-18; Manfred Zollinger, Bibliographie der Spielbücher des 15. bis 18. Jahrhunderts, vol. 1: 1473-1700 (Stuttgart: Hiersemann, 1996). Zollinger does not mention any Polish book of fortune-telling, whereas Bolte listed works of Stanisław Kleryka, Seweryn Bączalski, and Jan Gawiński following Karol Estreicher's Bibliografia polska. See Bolte, 'Anhang', p. 308. 
of a town. In this way, 21 'bird spheres' guided the reader to the 21 'spheres of the animals' - the second set of 'wheels of fortune', above which animal images presided. Here the reader had to find the name of the relevant town, because next to it a reference was added to the list of twelve Sibyls, who each had 37 predictions to give. After the enquirer had found their way through these stages, he or she was able to reach the supposedly relevant answer. At the location determined in fact by the dice throw, the reader would be provided with an oracle: favourable or unfavourable, humorous or simply offensive.

For example, when the enquirer wanted to know if they should live a long life ("Jeśli kto będzie długo żyw"), they would open Fortuna at the page where a wheel of fortune was printed with a gander at the centre (ill. 6.1). When the dice happened to turn up, for example, six and six, the reader would be referred to the woodcut sphere with the picture of a sable and asked to look there for the name of the village Bochnia (ill. 6.2). Finding it leads to the oracle number one given by 'Sybilla Persica' (ill. 6.3). The answer reads: “Żadnemu Bóg nie raczył dać tego, / Iżby wiedział wiek zdrowia swego; / Wszakże to powiem iście tobie, / Że ty pomieszkasz na świecie sobie" [I, 1] ["God has hidden from us the date of our death; But I will tell you the honest truth: you are going to stay in the world long enough"].

\section{Editio princeps of Fortuna: Date and Printer}

Losbücher, libros di ventura and livres de bonne chance were popular all over Europe especially in the fifteenth and sixteenth centuries. In fact, browsing through the seventeeth-century copies of Fortuna abo Szczęście tells us immediately that the work itself, even if known today from copies produced in $1640 \mathrm{~s}$ and 1660 s is a much earlier one. In the rhymed introduction the book's author introduces himself to the readers as 'Stanisław z Bochnie'. Thus Fortuna must have been composed in the first decades of the sixteenth century, since Stanisław z Bochnie Gąsiorek was a poet and a composer who had died some time before 1561. Active in Krakow Stanisław was serving at the court of Zygmunt I (Sigismund I the Old, 1467-1548) as the king's most prominent chaplain, and for that reason he was also called Kleryka. ${ }^{5}$ Kleryka's poetical legacy consists primarily of occasional, panegyric poetry composed in the vernacular and published by Krakow printers in 1520 and 1530 . This in turn provides a hint that the editio princeps of Fortuna was also printed in one of the city's workshops in those years.

5 Helena Kapełuś, Stanisław z Bochnie, kleryka królewski (Wrocław: Ossolineum, 1964). 


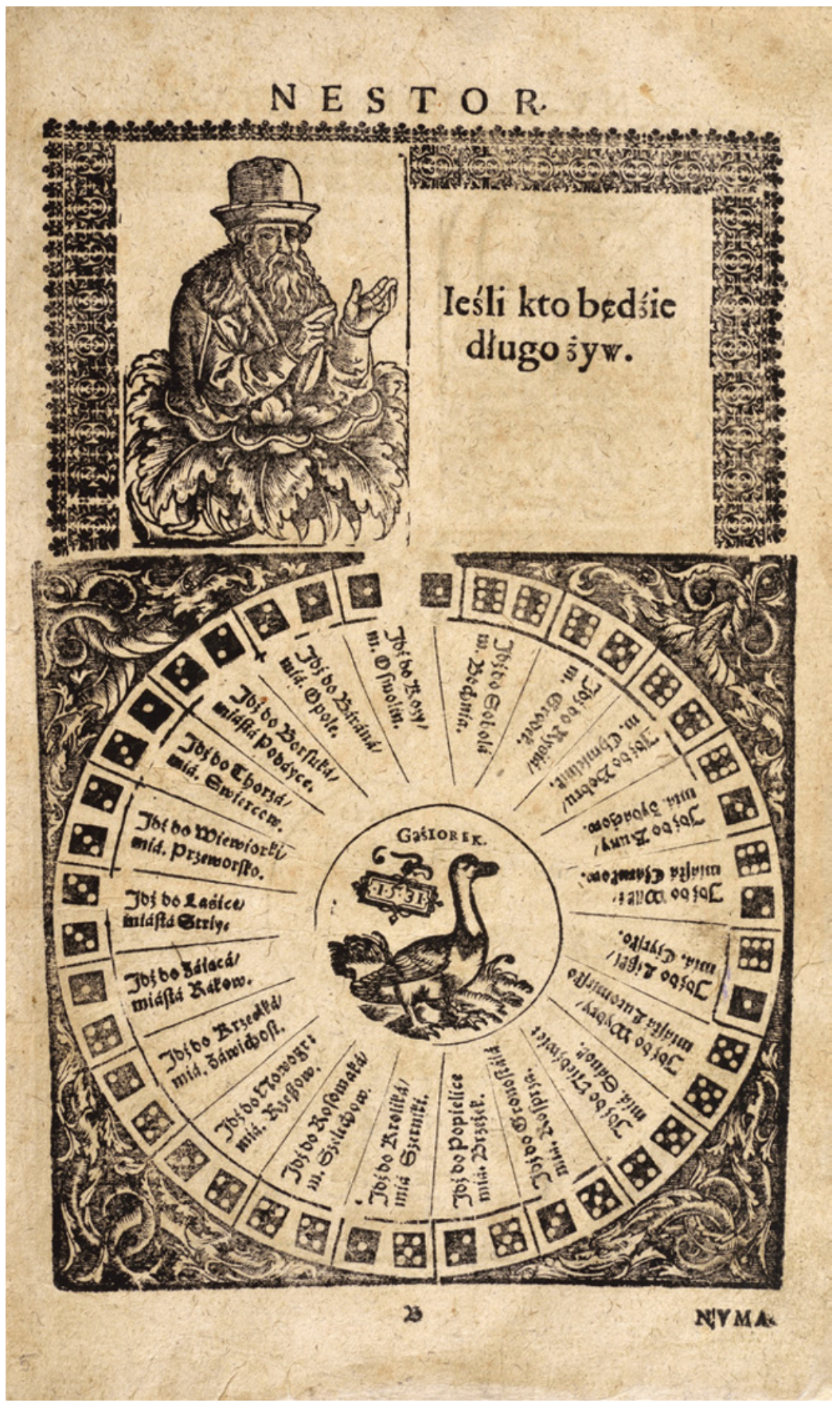

Illustration 6.1 Stanistaw Kleryka, Fortuna abo Szczęście (Kraków: Drukarnia Dziedziców Stanisława Bertutowica, 1665)

(C) Strahovska Knihovna v Klastere Premonstratu, Prague [AG XII 25] 


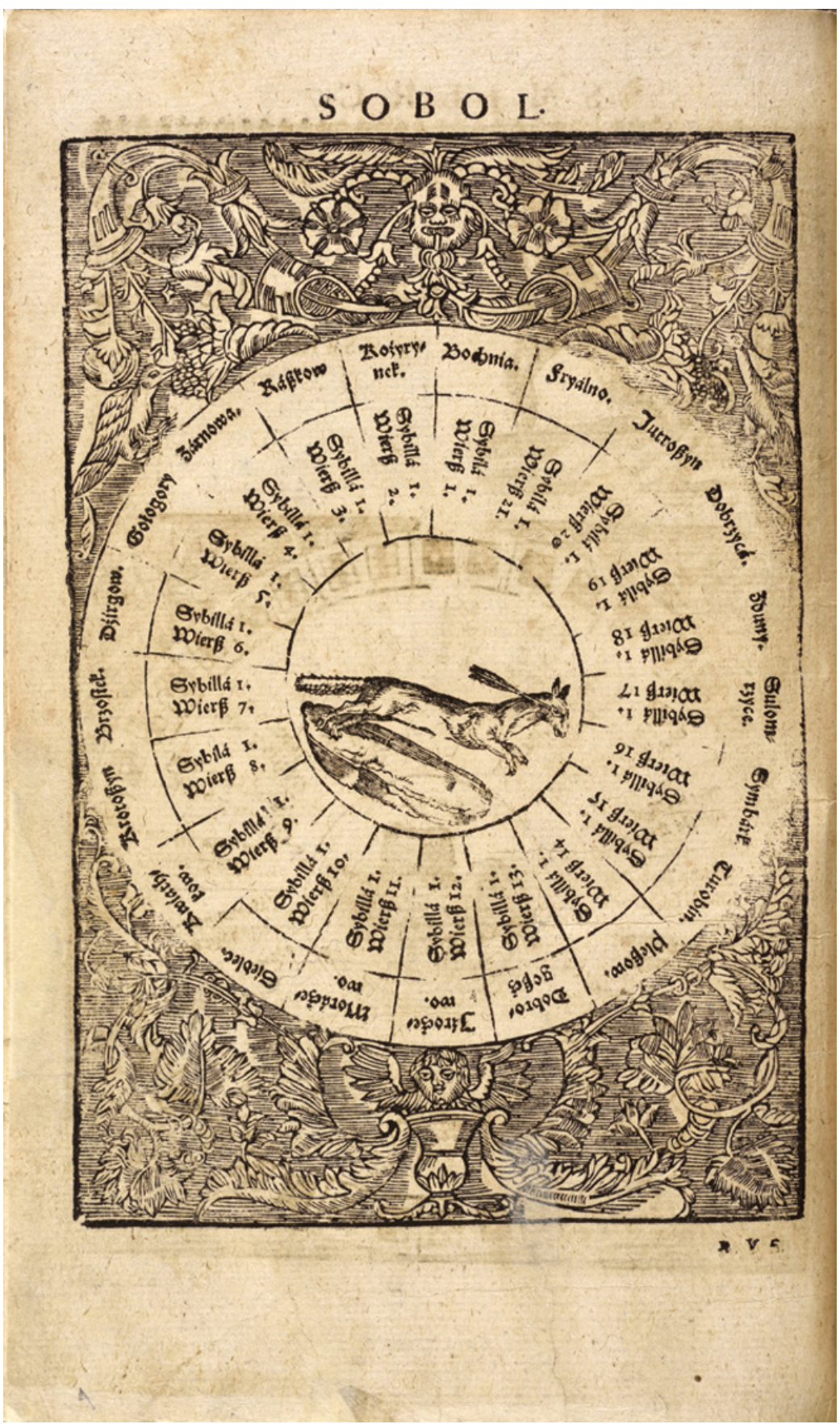

Illustration 6.2 Stanisław Kleryka, Fortuna abo Szczęście (Kraków: Drukarnia Dziedziców Stanistawa Bertutowica, 1665)

(C) Strahovska Knihovna v Klastere Premonstratu, Prague [AG XII 25] 


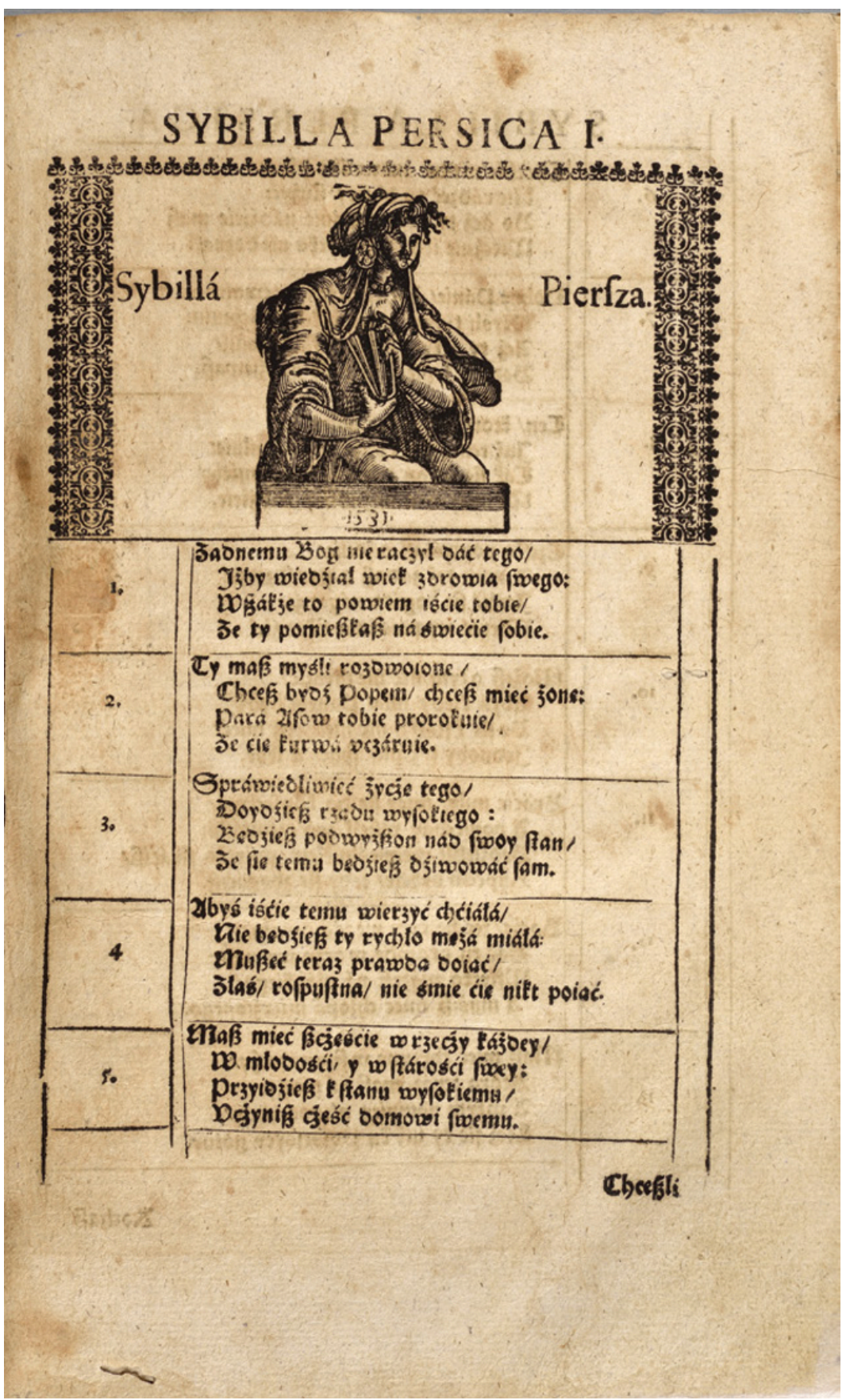

ILLUSTRATION 6.3

Stanistaw Kleryka, Fortuna abo Szczęście (Kraków: Drukarnia

Dziedziców Stanistawa Bertutowica, 1665)

(C) Strahovska Knihovna v Klastere Premonstratu,

Prague [AG XII 25] 
This working hypothesis is confirmed by the woodcut evidence given by the later seventeenth-century copies of Kleryka's work. Examination of the 1665 volume and the fragmentary copy printed in the 1640 s reveals that both editions were produced using a very similar set of woodblocks. The printers made do, for the most part, with worn, second-hand cuts originating mostly in the sixteenth century. The sixteenth-century illustrations include not only generic figures, but also images closely connected with the content and structure of Fortuna. These include representations of Fortuna-Occasio in classical costume, the image of the wheel of Fortune in accord with Mediaeval iconography, and - more importantly - stylistically uniform series. The first of the series consists of birds and animals and the other is a parade of twelve Sibyls. Both must have been designed and cut with an eye to producing Fortuna: birds and animals to be set in the centre of wheels of fortune, and the Sibyls to preside over the prediction pages. Hence the significance of the fact that the two woodcuts belonging to these series - the image of 'gąsiorek' (a gander) (ill. 6.1) and the conventional portrait of 'Sybilla Persica' (ill. 6.3) - bear the date 1531, suggesting that the first edition of Fortuna abo Szczęście was printed about that time, most probably after 1531. Interestingly the woodcuts with these dates were not chosen accidentally. Both illustrations open the series to which they belong; the image of a gander is also a pun, or a rebus signature: Gąsiorek was the family name of Stanisław z Bochnie. ${ }^{6}$

Examination of the woodcuts used to produce the seventeenth-century copies of Fortuna abo Szczęście strongly suggests not only the date of the work's editio princeps, but also its printer, as some of the illustrations of the 1640 and 1665 editions are also to be found in books produced in the first decades of the sixteenth century. Most notably this is the case with the birds and the animals that rule the game in Fortuna and belong to the series in all probability commissioned for Kleryka's work (compare ills. 6.4 and 6.5). Also the generic portraits (in Fortuna representing mythical characters) appear in numerous books, the earliest of which were printed in the 1530 (compare ills. 6.1 and 6.6). ${ }^{7}$

6 On this tradition see Béatrice Fraenkel, 'La signature et le rébus de nom propre', in Martin Heussner et al. (eds.), Word and Image. A Selection of Papers Given at the Second International Conference on Word and Image (Basel: Wiese, 1993), pp. 35-40.

7 See e.g. Istoryja o świętym Jozefie (Kraków: Hieronim Wietor, 1530), copy at Biblioteka Jagiellońska, Kraków, Cim 103 (Nestor in Fortuna); Piotr Ciświcki, Adolescentis epistola (Kraków: Hieronim Wietor, 1535), copy at Biblioteka Kórnicka, Cim O.81 (Orestes and Pylades in Fortuna); Andreas Guarna, Grammaticae opus (Kraków, Hieronim Wietor: 1534), copy at Biblioteka Ossolineum, XVI.O.471 (Fabius in Fortuna). 


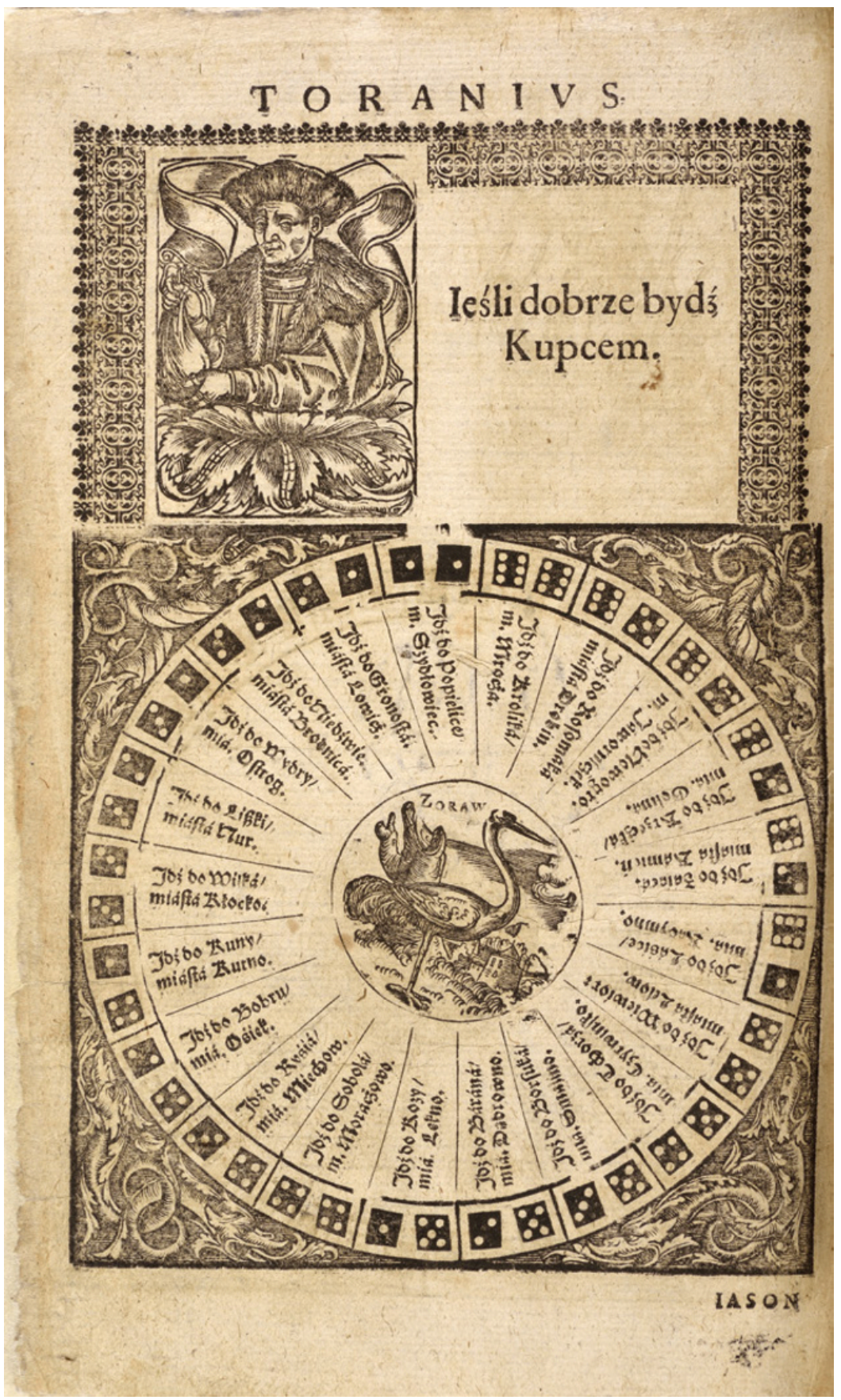

Illustration 6.4 Stanisław Kleryka, Fortuna abo Szczęście (Kraków: Drukarnia Dziedziców Stanistawa Bertutowica, 1665)

(C) Strahovska Knihovna v Klastere Premonstratu, Prague [AG XII 25] 


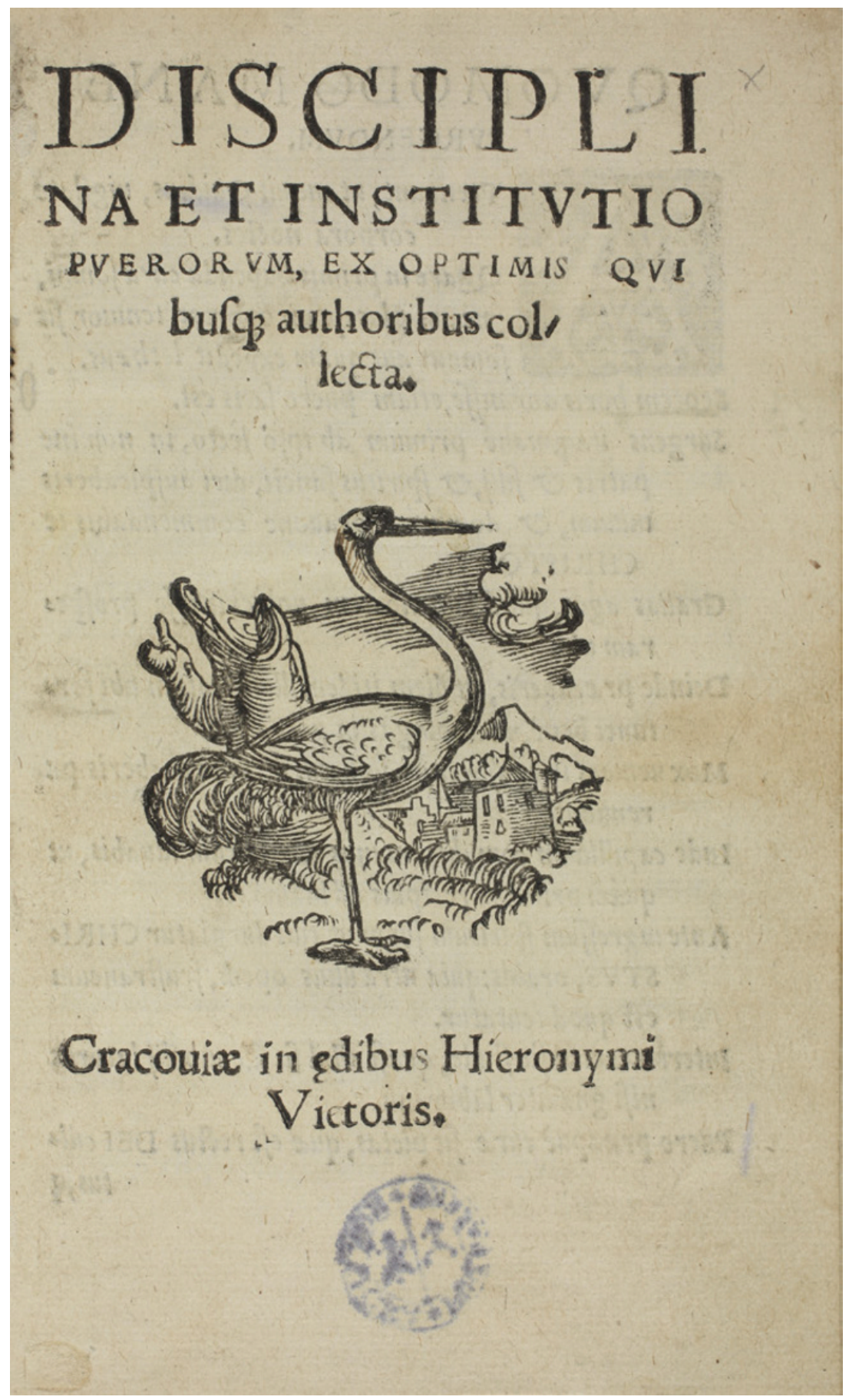

ILlUSTRATION 6.5 Disciplina puerorum (Kraków: Hieronim Wietor, post 1541)

(C) Biblioteka Kórnicka [Cim O.335] 


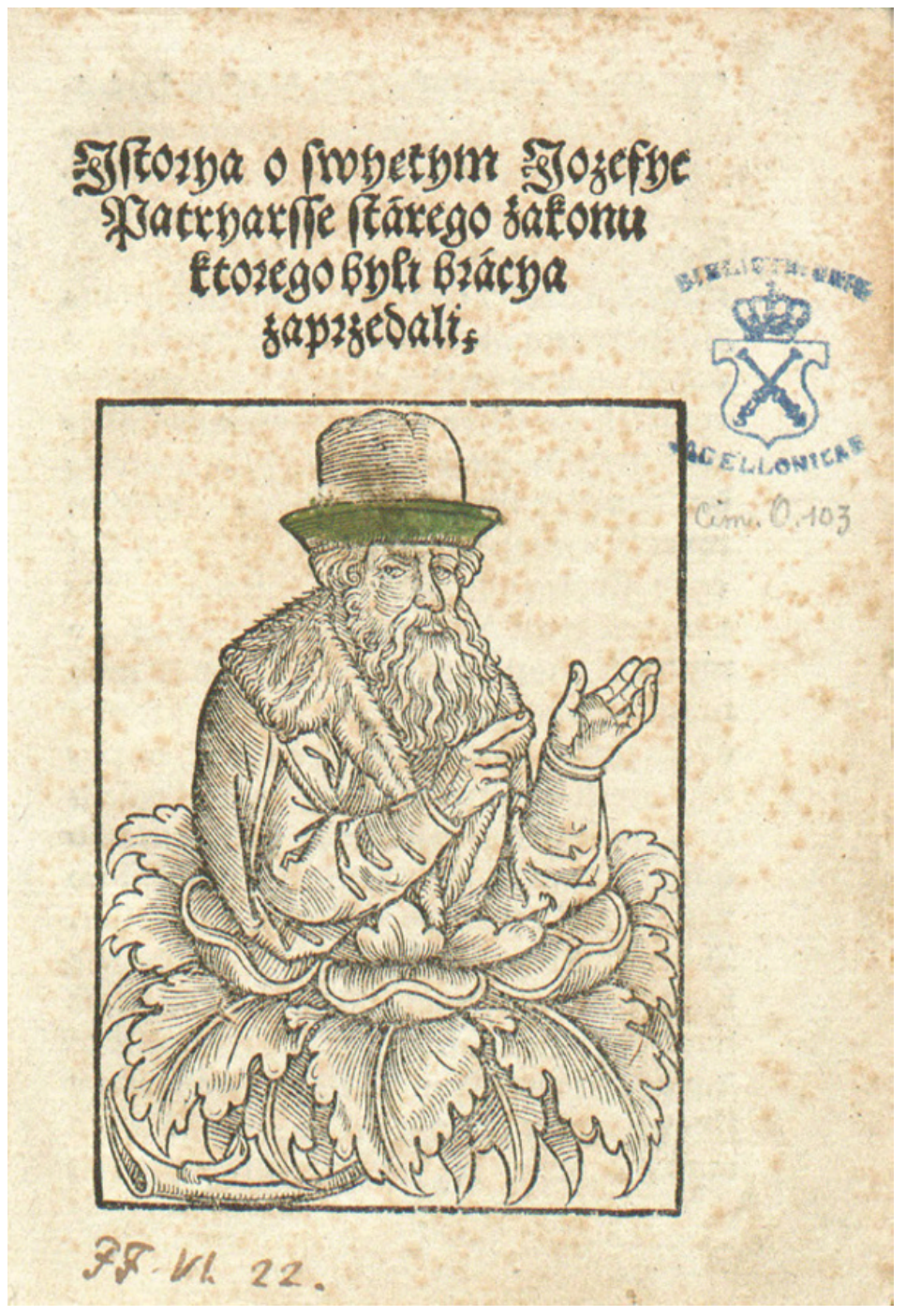

ILlUStration 6.6 Istoryja o świętym Jozefie (Kraków: Hieronim Wietor, 1530)

(C) Biblioteka Jagiellońska, Kraków [Cim 103]

Since the early sixteenth-century imprints that make use of the woodcuts otherwise known from Fortuna originate in the workshop of Hieronim Wietor, a printer active in Krakow between 1518 and 1546, it seems reasonable to assume that is was Wietor who was responsible for the first, lost edition of Fortuna. ${ }^{8}$

8 Anna Mańkowska, Alodia Kawecka-Gryczowa, 'Hieronim Wietor', in Alodia KaweckaGryczowa (ed.), Drukarze dawnej Polski, vol. 1: Małopolska, part 1: Od XV do XVI wieku (Wrocław: Ossolineum 1983), pp. 325-352. 
The woodcut evidence suggests that to print his books Wietor used blocks with generic illustrations as well as those that belonged to the series commissioned to produce Fortuna about 1531. To have a set of woodblocks cut was a costly investment, so it made sense to exploit it in more than one book, as well as employ the blocks over a period of decades, as Wietor did.

Crediting Hieronim Wietor with the Kleryka's collection's first edition accords with the reconstruction of the way woodblocks he once owned came into the possession of the seventeenth-century printers of Fortuna. In fact, the printing shop established by Wietor in platea Columbarum in Krakow was first inherited by Barbara Wietorowa, Hieronim's widow, then by her second husband Łazarz Andrysowic, and finally by Jan Łazarzowic Januszowski, the only son of Barbara and Łazarz. ${ }^{9}$ Januszowski gave up printing at the beginning of the seventeenth century. After a few years, the material that originated from Wietor's shop was purchased by MaciejJędrzejowczyk, who in turn left it to his son-in-law Walerian Piątkowski (in the late 1640s Piątkowski produced the Fortuna copy that is incompletely preserved at the National Library in Warsaw). The printing tools he owned and employed were consequently bought by Stanisław Bertutowic and then used as well by his heirs, who in 1665 published another Fortuna edition (the only recorded copy being the volume at the Strahov Monastery Library in Prague). Early sixteenth-century woodblocks used to illustrate the seventeenth-century editions of Fortuna remained in the workshop in platea Columbarum for many decades. Employed first by Hieronim Wietor, they were next used by Barbara Wietorowa, then by Łazarz Andrysowic, and Jan Januszowski. ${ }^{10}$ In the seventeenth century these old woodblocks found new owners, and were re-used again.

Attributing the editio princeps of Fortuna to Hieronim Wietor seems even more justified considering the fact that Wietor was one of the first to publish books in Polish. He issued a number of editions in the vernacular at a time when printers were still learning how to deal with the technical difficulties raised by choosing Polish as the language of a printed text. At the end of the $15^{20}$ and the beginning of the 1530s, around the time Fortuna was first published, printing books in Polish was no longer an absolute novelty, but was still a practice adopted relatively recently. In Poland, printing started in 1473, but it

9 Justyna Kiliańczyk-Zięba, 'In Platea Columbarum. The printing house of Hieronim Wietor, Łazarz Andrysowic and Jan Januszowski in Renaissance Krakow', Publishing History, 47 (2010), pp. 5-37.

10 See e.g. Jan z Łańcuta, Algorithmus linealis (Kraków: Barbara Wietorowa, 1548), copy at Biblioteka Jagiellońska, Cim 141; Krzysztof Kobylański, Variorum epigrammatum libellus (Kraków: Łazarz Andrysowic, 1551) copy at Biblioteka Jagiellońska, Cim 4417. 
took some time before typographers learnt how to produce publications in the vernacular. Texts composed in lingua vulgari Polonica were originally added to more extensive Latin works: vernacular prayers were printed in Statuta synodalia episcoporum Vratislaviensium from 1475 (Wrocław, Kasper Elyan), Bogurodzica (Mother of God) in Commune incliti Poloniae Regni privilegium constitutionum by Jan Łaski from 1505 (Krakow, Jan Haller). ${ }^{11}$ Most probably, books printed entirely in the vernacular started to be produced soon after that, in the first decade of the sixteenth century. ${ }^{12}$

The first printer whose workshop produced a series of books in lingua vulgari Polonica in the opening decades of the sixteenth century was Florian Ungler, active in Krakow. On the Polish-language book market his competitor was Hieronim Wietor, a printer-humanist, who at the same time did not shun popular books that sold well. Wietor published his first book in Krakow in 1518 and, as early as in 1520, he printed Żywot świętej Anny (The Life of St Anne) by Jan z Koszyczek. He took over some Polish texts from Ungler, but he also encouraged local intellectuals to create new ones. A series of translations left Wietor's workshop in the 1520s, including Rozmowy, ktore miat krol Salomon madry $z$ Marchottem grubym a sprosnym (The Dialogue of Salomon and Marcolf, 1521) by Jan z Koszyczek and Ezop (Aesop, 1522) by Biernat z Lublina. Humorous and appealing to a popular audience, Fortuna seems to harmonise well with the Polish-language repertoire of Wietor: its edition of about 1531 emerged out of and further developed an existing vernacular printing tradition.

\section{Illustrations and Layout of Lost Editions}

When a book of fortune-telling was reprinted in successive editions, its content and structure, as well as the woodcuts and typographic design, usually followed those of the first imprint. The tendency is best observable in the illustrated editions of Il libro delle sorti by Lorenzo Spirito - the most popular early modern book of fortune-telling. Most editions of Spirito's collection in Italian reflect

11 Wiesław Wydra, Wojciech Ryszard Rzepka, 'Niesamoistne drukowane teksty polskie sprzed roku 1521 i ich znaczenie dla historii drukarstwa i języka polskiego', in Stanisław Grzeszczuk and Alodia Kawecka-Gryczowa (eds.), Dawna ksiażka i kultura. Materiaty międzynarodowej sesji naukowej z okazji pięćsetlecia sztuki drukarskiej w Polsce (Wrocław: Ossolineum, 1975), pp. 263-288.

12 The discussion about the beginnings of printing in Polish and controversies raised by the subject are summarised by Danuta Bacewiczowa, Kasper Hochfeder, in KaweckaGryczowa (ed.), Drukarze, pp. 65-66. 
either the continued use of the same woodblocks, or use illustrations based on earlier cuts; at the same time the arrangement of the text and woodcut material is imitated or re-created. ${ }^{13}$ More interestingly the same is true for the translations of Il libro into other European vernaculars, especially French: although subsequent editions differ from each other, they all feature the layout of earlier volumes, as a consequence echoing incunabula copies of Spirito's work. ${ }^{14}$

It is thus equally conceivable that in the case of the Polish Fortuna the layout of the edition produced about 1531 is reflected in the design of the uniquely preserved copies issued more than a century later. This assumption can be placed in a context that would verify the hypothesis. Firstly, both the fragmented copy from the 1640 s and the 1665 book duplicate the same structure and feature an identical layout. The volumes are opened by two full page woodcuts representing Fortuna-Occasio and the mediaeval wheel of Fortune, followed by introductory poems, instructions for playing the games, and the list of questions the readers were to choose from when consulting the book of fate. After that come pages that each contain in the upper-half a query and a woodcut portrait of a mythical figure associated with a respective life dilemma, and in the lower part the woodcut material (decorative borders, representations of birds and animals ruling the game) together with text type (text describing the result of the thrown dice) (compare ills. 6.1 and 6.7). The final pages give answers to the game. Four-line, rhymed oracles are numbered and separated by rules. The predictions are printed arranged in twelve groups and the opening page of each group is headed by a portrait of a Sibyl (compare ills. 6.3 and 6.8). Admittedly the design of the 1665 edition is slightly less sober, since the vertical lines are replaced with ornamental borders composed of tiny elements. Even if both editions do not always conform absolutely, either the 1665 edition is a page for page reprint of the one produced in 1640 , or they both follow the design of an earlier, lost book. Whatever the exact relationship of these preserved copies to each other, in all probability they both in fact feature the layout of a much earlier, possibly sixteenth-century, edition, the design of which certainly echoed the typographical project of the editio princeps.

Secondly, considering the fact that the printers who produced the seventeenth-century volumes of Polish Fortuna re-used woodcuts over a hundred

13 Tammaro de Marinis, 'Le illustrazioni per il libro de le sorte di Lorenzo Spirito', in Tammaro de Marinis, Appunti e ricerche bibliografiche (Milan: U. Hoepli, 1940), pp. 69-83; Daniel de Simone (ed.), A Heavenly Craft. The Woodcut in Early Printed Books (New York: George Braziller, 2004), pp. 157-159.

14 Andrew Pettegree, Malcolm Walsby and Alexander Wilkinson, French Vernacular Books. Books Published in the French Language before 1601 (Leiden: Brill, 2007), nos. 48472-48488. 


\section{N E $S$ S $T$ T O $R$}

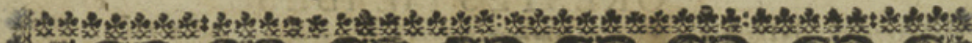

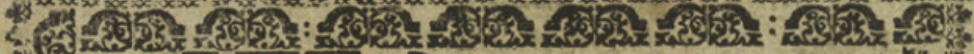
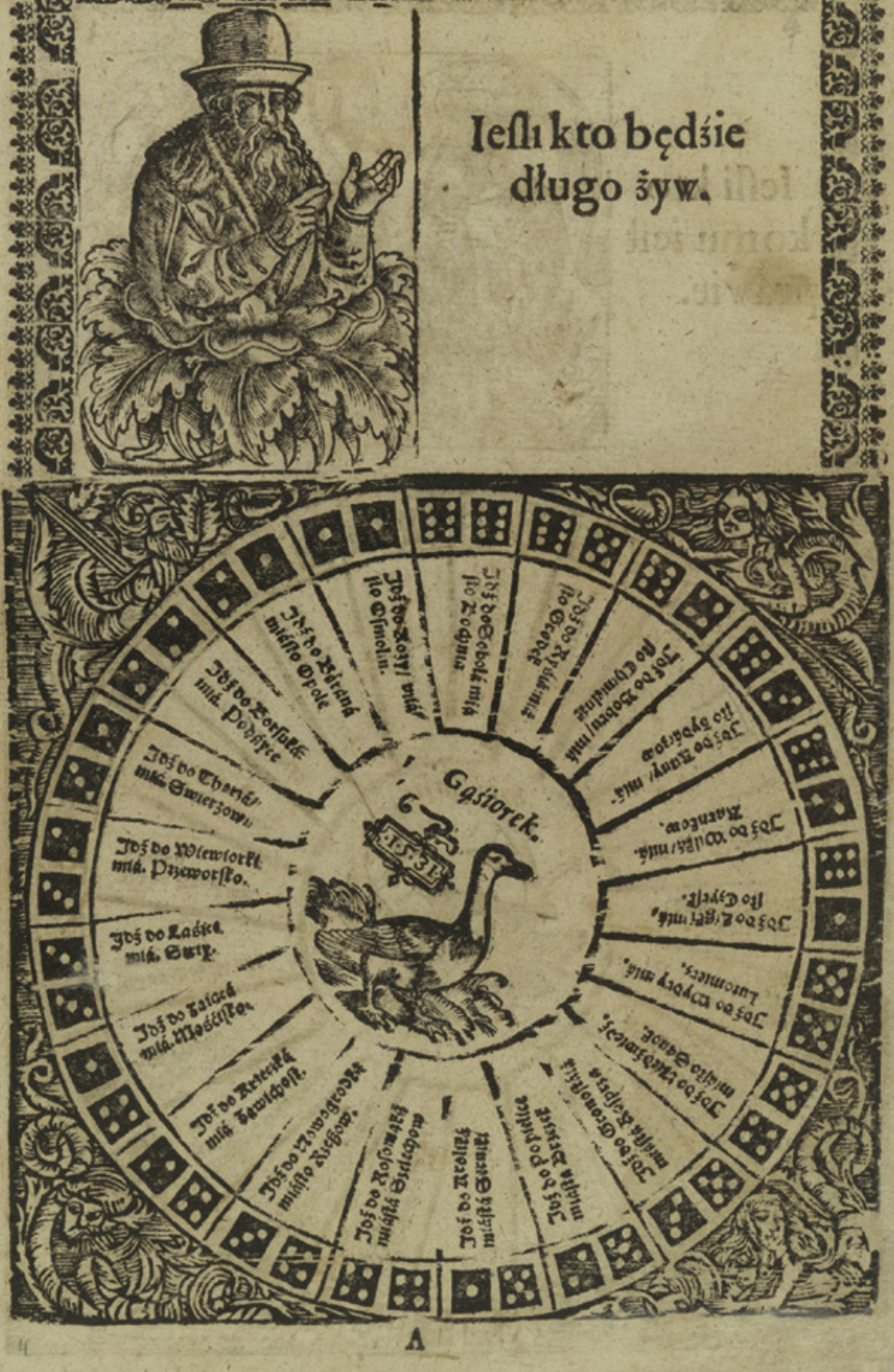

ILluStration 6.7 Stanistaw Kleryka, Fortuna abo Szczęście (Kraków: Drukarnia Waleriana Piatkowskiego, [1646-1652])

(c) Biblioteka Narodowa, Warsaw [XvII.4.3504] 


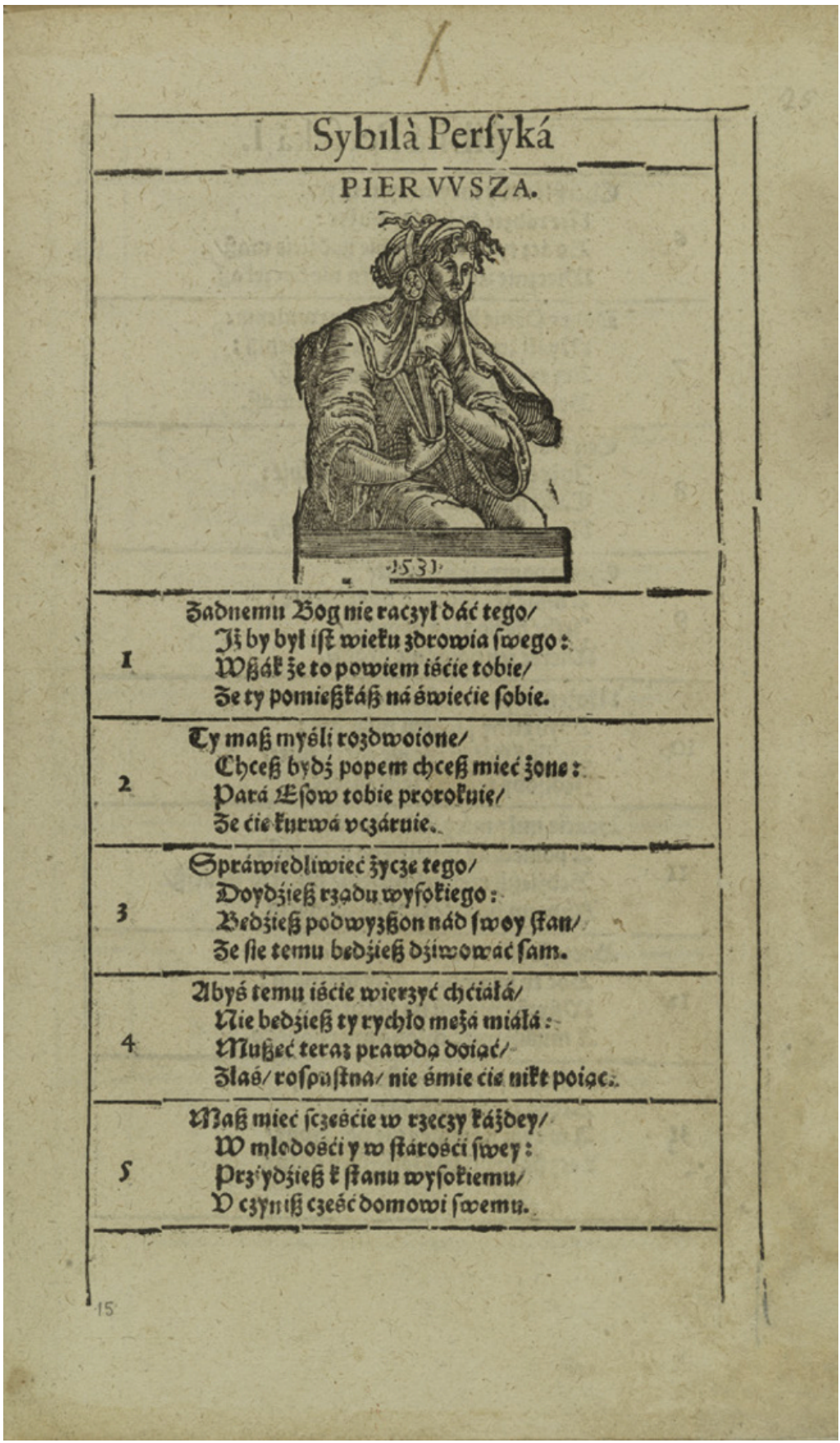

Illustration 6.8 Stanisław Kleryka, Fortuna abo Szczęście (Kraków: Drukarnia Waleriana Piatkowskiego, [1646-1652])

(c) Biblioteka Narodowa, Warsaw [XVII.4.3504] 
years old, some of which were cut specially for the edition of c. 1531, it is probable that the great part of the illustrative material found in the later preserved copies had already been used in the editio princeps of Kleryka's book. Even if some of the woodcuts originally employed were replaced by more recently designed illustrations, it is reasonable to assume that at least the woodcuts owned by Hieronim Wietor in the 1530s, especially those commissioned for the book of fortune-telling (e.g. the Sibyls) were accommodated within the volume printed about 1531 in the same places as in the seventeenth-century editions. As a consequence a study of the seventeenth-century volumes allows a reconstruction of the typographical structure of the first edition of Fortuna.

This observation seems more justified when we look at the editions of Fortuna translated into Hungarian in the sixteenth century, as well as a copy published in Krakow in the eighteenth century. The Hungarian version of Kleryka's collection is preserved in unique fragmentary copies, representing two different editions printed at the end of the sixteenth or beginning of the seventeenth century..$^{15}$ The copy named Fortuna was probably produced in 1599-1610 in Kolozsvár (presently Cluj-Napoca in Romania). The copy named Sybillák jövendölése (Sibyls' oracles) is thought to have been printed around 1616 in Bártfa (presently Bardejov in Slovakia). It transmits an older, sixteenth-century variant of the oracles' text, which suggests that an earlier edition of this work might have existed. This assumption is further corroborated (just as in the case of the Polish book of fortune-telling) by woodcut evidence: illustrations from the book of fate designed series are found in a number of sixteenth-century books. Futher proof is offered by the printer's preface in the Kolozsvár volume, where an edition of the work produced a few years before is explicitly mentioned.

The unknown author of the Hungarian book of fortune-telling translated the Polish text and copied the structure of Kleryka's collection. More importantly for our purpose the layout of Fortuna and Sybillák jövendölése is also clearly dependent on a volume imported from Krakow, even though both Hungarian editions were issued in quarto whereas the Polish Fortuna was a

15 The information about the Hungarian translation of Fortuna is quoted after Helena Kapełuś, Jan Ślaski, 'Polski druk popularny na Węgrzech. Z dziejów "Fortuny”', Rocznik Biblioteki Narodowej, 2 (1966), pp. 297-317; Gedeon Borsa, 'Hol és mikor nyomták az eddig ismert két legrégibb magyar sorsvetö könyvet?', in Gedeon Borsa, Könyvtörténeti írások I. A hazai nyomdászat 15-17 század (Budapest: Országos Széchényi Könyvtár, 1996), pp. 29530o; Gedeon Borsa, 'A "Fortuna" sorsvetökönyv eredete és utóélete', in Gedeon Borsa, Könyvtörténeti írások I. A hazai nyomdászat 15-17 század (Budapest: Országos Széchényi Könyvtár, 1996), pp. 301-306. The edition printed about 1594 is mentioned in Gedeon Borsa (ed.), Alte siebenbürgische Drucke (16. Jahrhundert) (Cologne: Böhlau Verlag, 1996), no. 361. Digital facsimile of Fortuna is available online: $<$ http://oszkdk.oszk.hu/DRJ/6764>. 
folio book. Hungarian printers had the woodblocks cut after the Polish example, though the images in their editions are more naturalistic and less stylised then the illustrations that had been commissioned by Hieronim Wietor. The pages with the oracles' text have been set up following the plan familiar from the 1640 and 1665 unique copies of the Polish Fortuna. Naturally a copy representing one of these editions could not serve as a model for the Hungarian printers, whose edition pre-dates them by the best part of a hundred years. The editions from Kolozsvár and Bártfa feature instead the layout of an older sixteenth-century book that in turn most probably followed the design of the editio princeps originating about 1531 in the workshop of Hieronim Wietor.

The tendency to imitate the layout and illustrations of older editions of Kleryka's collection was established early on, as the copies of Fortuna's translations into Hungarian strongly suggest. That it became the firmly rooted custom is demonstrated not only by the 1640 s and 1665 volumes of Fortuna, but also by a mid-eighteenth-century book whose content is a new version of Kleryka's old work. Preparations to print an up-to-date edition of Fortuna began at the end of the seventeenth century. Jan Gawiński wrote rhymed oracles, using Kleryka's archaic verses as his starting point. ${ }^{16}$ Mikołaj Bereszniewicz provided new woodblocks, cutting them after illustrations in an old volume of Fortuna. Bereszniewicz signed his portrait of 'Sybilla Kumea' ('Nicolaus Bereszniewic sculpsit Cracov[iae] 1689') and dated the representations of a gander (1688) and 'Sybilla Persica' (1689) following the example of an anonymous woodcutter who worked for Wietor in 1531 (compare ills. 6.1, 6.9, 6.3, and 6.10). The fullpage wheel of Fortune was also dated (1678).

No known copy of a late seventeenth-century edition of Fortuna with Gawiński's text and Bereszniewicz's illustrations has come down to us. A copy certainly survived into the nineteenth century when it was recorded in a catalogue as printed by Drukarnia Akademii in Krakow, in $1690 .{ }^{17}$ Without this note by a nineteenthcentury bibliographer we would have to infer the existence of "an edition from about 1689" - and its illustrations and layout - by examining more recent copies of Gawiński's Fortuna that have been preserved until now. These were printed in Krakow in 1744 by Michał Dyjaszewski, who reused the woodblocks by Bereszniewicz and imitated the layout once featured in the editions of Kleryka's Fortuna. ${ }^{18}$

16 Dariusz Chemperek, Poezja Jana Gawińskiego i kultura literacka drugiej połowy XVII wieku (Lublin: Wydawnictwo U MCs, 2005), pp. 323-336.

17 Żegota Pauli, Poezyje Jana z Wielomowic Gawińskiego (Lwów: Jan Milikowski, 1843), pp. 19-20.

18 There are two copies of Gawiński's Fortuna registered in the union catalogue of the National Library in Warsaw: (1) at Biblioteka Narodowa, Warszawa, Xviır.3.5734; (2) at Biblioteka Ossolineum, Wrocław, XVIII.15649-IV. 


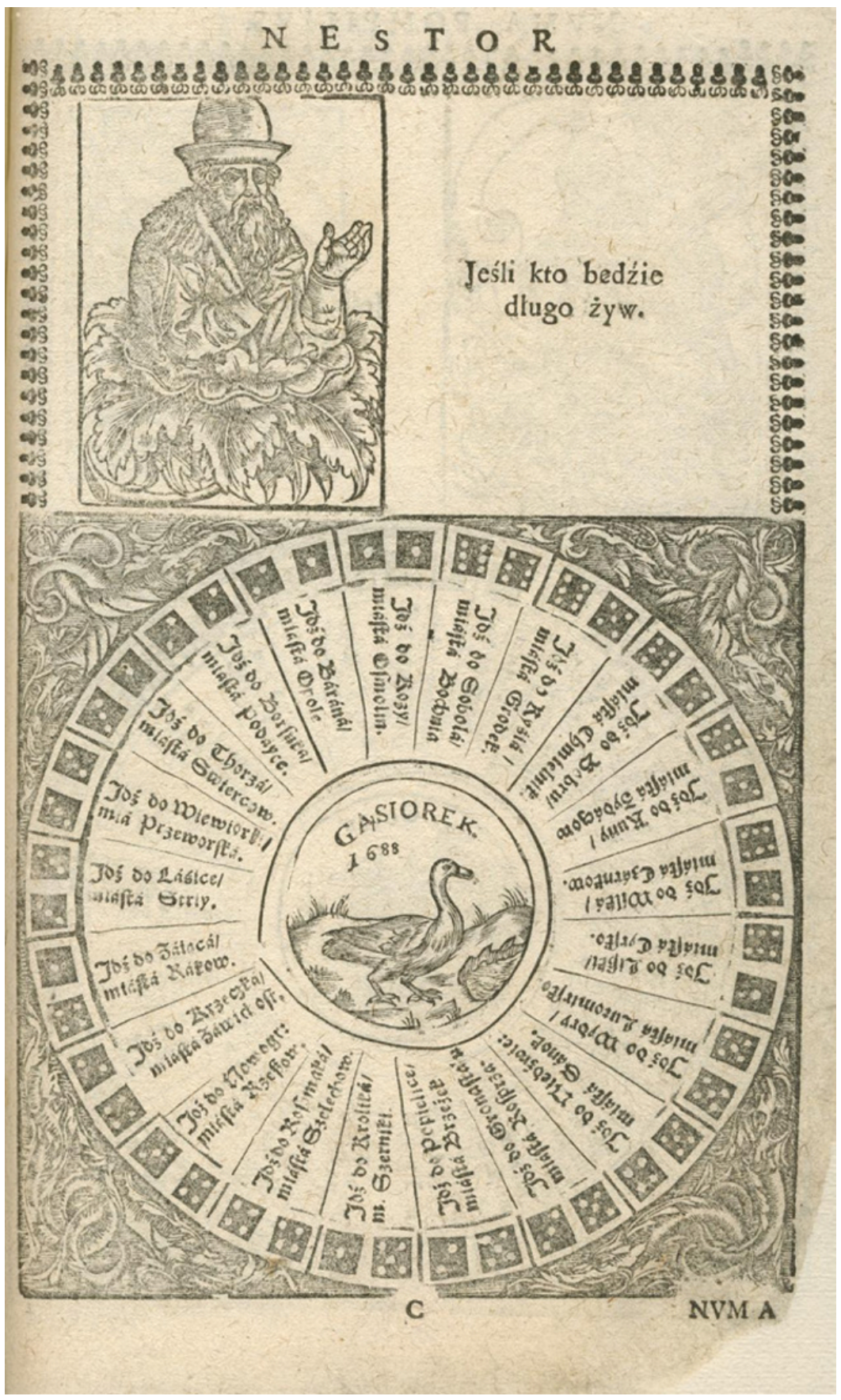

Illustration 6.9 Jan Gawiński, Fortuna albo Szczęście (Kraków: Michat Dyjaszewski, 1744) (C) Biblioteka Narodowa, Warsaw [XVIII.3.5734] 


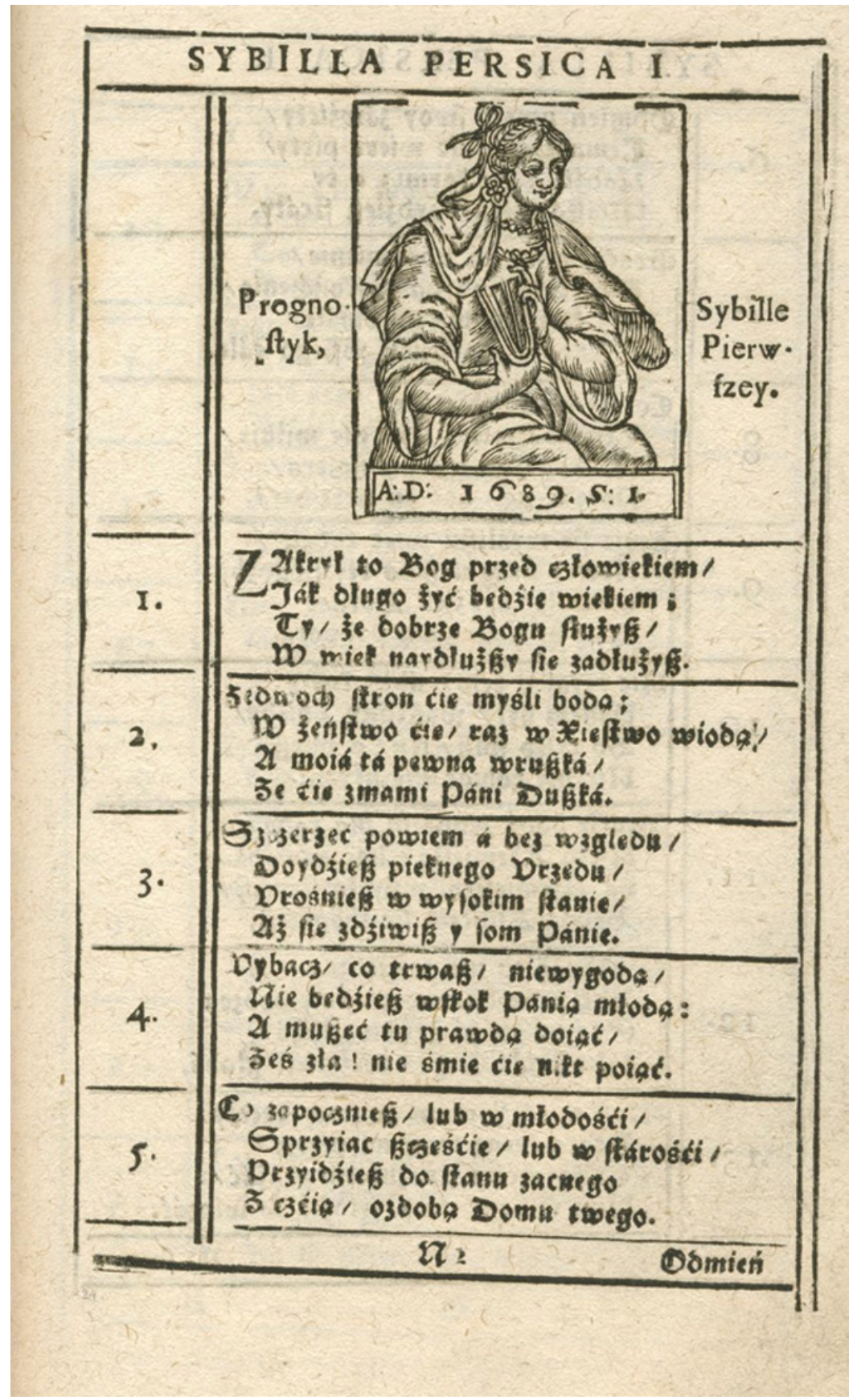

Illustration 6.10 Jan Gawiński, Fortuna albo Szczęście (Kraków: Michat Dyjaszewski, 1744) (C) Biblioteka Narodowa, Warsaw [XVIII.3.5734] 
Dyjaszewski probably modelled his volume on the book produced in 1690 (or one representing a later, now lost edition), but in fact he followed a much older design, as Gawiński's Fortuna from 1744 shows the same overall typographical structure as the volumes printed in the 1640 s and 166 os and therefore perhaps echoes the layout of the first edition of Kleryka's volume.

The typographical form of Kleryka's work was imitated, modified and recreated by subsequent generations of printers. The sixteenth-century layout maintained its appeal, in spite of the passing decades and even when the volume crossed geographical and national barriers. This certainly owed a lot to the traditionalistic attitude of Fortuna's printers and the woodcutters working for them, who were active in a milieu of limited financial resources, and where fresh talents were rare. But as well as this Fortuna's design must have been considered felicitous - functional and attractive - by the makers of the book and by its readers if no attempt was made to introduce a layout and illustrations inspired by new iconographical models, even for the editions produced a century or two after Kleryka's collection was first issued.

\section{Archival Records for Kleryka's Volume}

Scarce material traces provide evidence that Fortuna was reprinted in the sixteenth and seventeenth centuries: woodcuts suggest that the first edition of Kleryka's collection was produced c. 1531 by Hieronim Wietor; there is a tiny binding-waste fragment of a book from the 1570 s attributed to Jan Januszowski, ${ }^{19}$ a fragmentary copy printed in the late 1640 s by Walerian Piątkowski, and a complete 1665 volume produced by Bertutowic's heirs. The existence of four distinct editions can thus be documented. The fragmentary survival of all but one of these raises the reasonable possibility that there were more editions produced after $153^{1}$ and in the first decades of the seventeenth century, as the rarity and incompleteness of preserved volumes often suggests that a title might have been frequently reprinted, only for copies to be read or used until quite worn out. In the same way, since most of Il libro delle sorti editions preserved until today are represented by unique or incomplete copies it has been suggested that Spirito's work have been printed more frequently than bibliographical evidence implies. ${ }^{20}$

A further example of this phenomenon from a slightly different genre is provided by the fortunes in Polish of the popular comic tale Marcolf. Hieronim

19 Kapełuś, Stanistaw, pp. 79-80.

20 Rosenstock, Das Losbuch, p. 16. 
Wietor printed at least six editions of Rozmowy...z Marchottem between the years 1521 and 1553 . We would have no bibliographical evidence confirming the existence of most of them if not for Kazimierz Piekarski who discovered binding-waste fragments that represent four separate editions. ${ }^{21}$ Kleryka's book of fortune-telling was certainly less popular (and more expensive) than Rozmowy...z Marchottem, and as such, it was printed less frequently. Nonetheless, the Marcolf adventures demonstrate that the readers' favourite recreational books had the potential to be re-printed every few years during their period of peak demand. We can conclude per analogiam that apart from the four editions of Fortuna mentioned above there must have been others. As survival depends primarily on the nature of early ownership, Fortuna copies did not have a high chance of preservation. Fortuna readers did not give thought to the long-term preservation of a book that promised a pleasant, undemanding read or could be consulted in the company of friends and used for social entertainment. Books of fortune-telling would not be bought by or given to an institution with a formal library such as a convent or a university where the volumes had a better chance of survival. ${ }^{22}$

Some publishing details for Kleryka's book of fortune-telling are documented in archival sources. Unfortunately, no sixteenth-century book inventories or other contemporary documents I have consulted have preserved any records on editions of Fortuna originating from the workshop of Hieronim Wietor, his wife Barbara or her second husband, tazarz Andrysowic, although Kleryka's book could have been reprinted there in the decades after 1531. Fortuna is mentioned, however, in an inventory of 'things that belonged to the deceased Maciej Przywilcki', a bookbinder from Krakow. ${ }^{23}$ The inventory was compiled in 1587 , so it is possible then that the two copies of Fortuna in folio, listed therein, represent the same edition as the fragment printed in the $1570 \mathrm{~s}$ in Oficyna Łazarzowa of Jan Januszowski that was found hidden away in a late sixteenth-century binding.

21 Kazimierz Piekarski, 'Fragmenty czterech nieznanych wydań Marchotta', Pamiętnik Literacki, 32 (1935), pp. 481-520.

22 Paul Needham, 'The late use of incunables and the paths of book survival', Wolfenbütteler Notizen zur Buchgeschichte, 29.2 (2004), pp. 39-41.

23 Archiwum Narodowe w Krakowie, Libri scabinalia Cracoviensia, 207, pp. 948-957; Adam Chmiel, 'Inwentarz rzeczy introligatora krakowskiego Macieja Przywilckiego z roku 1587', Silva Rerum, 4 (1928), pp. 175-180; Justyna Kiliańczyk-Zięba, The book inventory of the sixteenth-century Krakow bookbinder, Maciej Przywilcki', in Malcolm Walsby and Natasha Constantinidou (eds.), Documenting the Early Modern Book World. Inventories and Catalogues in Manuscript and Print (Leiden: Brill, 2013), pp. 263-282. 
In the second decade of the seventeenth century Kleryka's book of fortunetelling was printed by MaciejJędrzejowczyk, who purchased Oficyna Łazarzowa from the sons of Jan Januszowski. Archival records mention that Jędrzejowczyk had a valuation done on a copy of Fortuna in $1618 .{ }^{24}$ That an edition of Kleryka's work was published around that time is also confirmed by a post-mortem inventory of Wawrzyniec Latowicki, a bookbinder from Lublin, compiled in 1619: eight copies of Fortuna in folio were listed among the possessions of the deceased. ${ }^{25}$

Another edition of Fortuna was most probably published in the late 1630 s. This is suggested by the archival record on Walerian Piątkowski, Maciej Jędrzejowczyk's son-in-law. After the old master's death in 1638, Piątkowski complained that some of the quires of a Fortuna edition which had already been printed were missing from the workshop he inherited. ${ }^{26}$ Piątkowski himself printed Fortuna at the end of the 1640s, but it seems unlikely that he published any other editions of the old collection: there are no records concerning the printer after 1649 .

Walerian Piątkowski's printing office was taken over by Stanisław Lenczewski Bertutowic, who probably died around 1657. In 1658 his heirs (Bertutowic's widow, Katarzyna, and his sons) were granted a royal privilege for the printing of a series of books, which must have been selling very well if the office decided to apply for a document safeguarding their rights. Among prayer books and primers, the privilege mentioned Fortuna in folio - unquestionably Kleryka's book of fortune-telling, apparently still bringing in significant profits. ${ }^{27}$ The workshop, which was not managed by Bertutowic's widow herself but by Jan Kubiński, produced at least one edition of Fortuna, known from the unique copy of 1665 at the Strahov library in Prague. It is likely that copies of that same edition are also mentioned in an inventory of Kubiński's possessions that was drawn up in 1669 after the manager of the Bertutowic printing office had left

24 Renata Żurkowa, 'Walerian Jerzy Piątkowski', in Jan Pirożyński (ed.), Drukarze dawnej Polski od XV do XVIII wieku, vol. 1: Matopolska, part 2/2 (Kraków: Polska Akademia Umiejętności, 200o), p. 482 (“jeden jej egzemplarz [MJ] dał bowiem do fachowej wyceny").

25 Archiwum Państwowe w Lublinie, Acta testamentorum et inventariorum, 126, pp. 258-267; Elżbieta Torój, Inwentarze książek lubelskich introligatorów z pierwszej potowy XVII wieku (Lublin: Wydawnictwo UmCs, 2000).

26 Żurkowa, 'Walerian Jerzy Piątkowski', p. 472 (“od tyż Fortunej kart wydrukowanych ryz półpiętej").

27 Teodor Wierzbowski, Materiaty do dziejów piśmiennictwa polskiego i biografii pisarzów polskich (Warsaw: Wydawnictwa Artystyczne i Filmowe, 1978), vol. II, pp. 85-86. 
Krakow to escape the plague. ${ }^{28}$ Various books in different stages of the production process are listed in this inventory, including 11 copies of Fortuna in folio.

If the Strahov copy of the Polish book of fortune-telling comes from the same edition as the books which once belonged to Jan Kubiński, it represents the last edition of Fortuna in which woodcuts originating in Hieronim Wietor's workshop formed the majority of illustrative material. Since Jan Kubiński never returned to Krakow, another inventory of the movables he had left in the city was made in 1681 . Among the things stored in the cellar of the house in which he had lived, the rotten and destroyed remnants of some printing materials were found, including the Fortuna woodblocks commissioned by Hieronim Wietor one hundred and fifty years earlier. ${ }^{29}$

The book of fortune-telling by Stanisław z Bochnie Kleryka enjoyed considerable longevity. Fortuna's text was adapted by epigones and translated into other languages, while the typographic form the collection acquired c. 1531 served as a model for printers of subsequent generations and the woodcutters who cooperated with them. Their work, together with archival evidence, allow us to draw conclusions about the existence of a series of editions of Fortuna, even if only the one produced in 1665 has been preserved in a complete, unique copy. Assumptions can be made also as to who produced successive editions and when they were printed. More interestingly, the design of the editio princeps as well as its reprints can be tentatively suggested. Copies of these lost editions might not have reached the safety of contemporary libraries, but they have not perished without trace.

28 "Spisanie rzeczy wszystkich, przez pana Jana Kubińskiego zostawionych i zamknionych", Archiwum Narodowe w Krakowie, Acta inventariorum, 256, pp. 1036-1044; Jan Kracik, 'Jan Kubiński - nieznany typograf krakowski Xviı wieku?' Biuletyn Biblioteki Jagiellońskiej, 39 (1989), pp. 13-16.

29 Archiwum Narodowe w Krakowie, Acta inventariorum, 258, pp. 284-287 ("relikwije drukarskich rupieci, co to wszystko...wniwecz pogniło i popsowało się"); Kracik, Jan Kubiński, p. 16. 